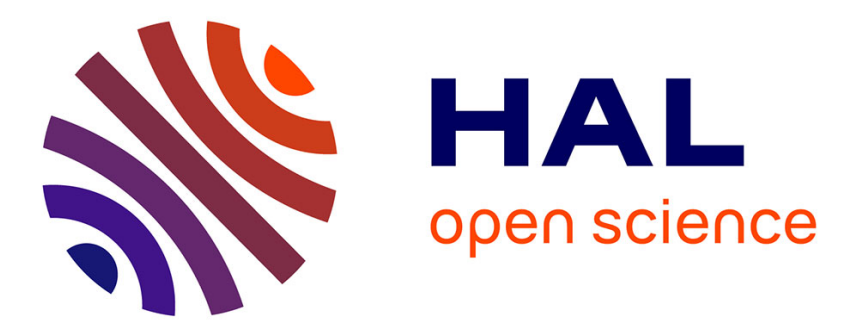

\title{
Long-term ecology of orchid bees in an urban forest remnant
}

\author{
André Nemésio, Leandro M. Santos, Heraldo L. Vasconcelos
}

\section{To cite this version:}

André Nemésio, Leandro M. Santos, Heraldo L. Vasconcelos. Long-term ecology of orchid bees in an urban forest remnant. Apidologie, 2015, 46 (3), pp.359-368. 10.1007/s13592-014-0328-8 . hal01284452

\section{HAL Id: hal-01284452 \\ https://hal.science/hal-01284452}

Submitted on 7 Mar 2016

HAL is a multi-disciplinary open access archive for the deposit and dissemination of scientific research documents, whether they are published or not. The documents may come from teaching and research institutions in France or abroad, or from public or private research centers.
L'archive ouverte pluridisciplinaire $\mathbf{H A L}$, est destinée au dépôt et à la diffusion de documents scientifiques de niveau recherche, publiés ou non, émanant des établissements d'enseignement et de recherche français ou étrangers, des laboratoires publics ou privés. 


\title{
Long-term ecology of orchid bees in an urban forest remnant
}

\author{
André NemÉsio ${ }^{1}$, Leandro M. SAnTos ${ }^{2}$, Heraldo L. VAsConCELos ${ }^{1}$ \\ ${ }^{1}$ Instituto de Biologia, Universidade Federal de Uberlândia, Rua Ceará, S/N, Campus Umuarama, Uberlândia, MG \\ 38400-902, Brazil \\ ${ }^{2}$ Laboratório de Biologia Comparada de Hymenoptera, Pós-graduação em Entomologia, Departamento de Zoologia, \\ Universidade Federal do Paraná, Caixa Postal 19.020, Curitiba, PR 81531-980, Brazil
}

Received 11 May 2014 - Revised 20 September 2014 - Accepted 8 October 2014

\begin{abstract}
Ecological studies lasting more than 1 or 2 years are not particularly common anywhere and in any taxonomic group. Ecological studies in orchid bees (Hymenoptera: Apidae) are not an exception and have focused on short-term scale. Long-term studies have been mostly neglected up to date. Orchid-bee males were attracted to five different scent baits in the same site every other year during a seven-year span, from 1997 to 2004, in an urban forest remnant, totaling four full years of samplings in between. In total, we captured 2188 bees from 14 species. Species diversity, evenness, and richness remained remarkably stable among years. The stability index, sensu Wolda, for the composite community revealed to be one of the highest ever recorded for insect communities. Our results suggest that orchid-bee populations may remain remarkably stable over the years even in a small ( $\approx 200$ ha) area immersed in a metropolitan $(\approx 3,000,000$ inhabitants) matrix and that these urban areas should not be neglected in conservation efforts, since they seem to maintain viable populations of these important pollinators over time.
\end{abstract}

\section{atlantic forest / community structure / conservation / euglossine bee/Euglossini/ population dynamics / stability index}

\section{INTRODUCTION}

Recently, many researchers have stressed the importance of long-term ecological studies for providing key insights in ecology, environmental change, natural resource management, and biodiversity conservation (reviewed by Lindenmayer et al. 2012). A common aim has been to identify key ecological processes that give rise to spatial and temporal patterns in the distribution, abundance or diversity of biota (e.g., Holmes and Sherry 2001; Krebs et al. 2001), or the causal factors underpinning environmental problems (Lindenmayer and Likens 2010). Thus, long-

Corresponding author: A. Nemésio, andre.nemesio@gmail.com Handling Editor: Klaus Hartfelder term studies can provide an improved understanding of complicated ecological systems (Lindenmayer et al. 2012 and references therein).

If the importance of long-term ecological studies is almost universally recognized, the definition of what constitutes a "long-term" study is not. According to Strayer et al. (1986), some researchers treat as long-term studies those that encompass several generations of organisms in a given ecosystem. Long-term studies, under this definition, would vary greatly depending on the life-span of the studied organisms. Other authors suggested an arbitrary duration for a research to be considered as a long-term ecological study, usually ranging from six (Wolda 1983) to ten (Lindenmayer et al. 2012) years of field data systematically and regularly collected from a particular site or set of sites.

Regardless the definition, ecological studies lasting more than 1 or 2 years are not particularly 
common anywhere and in any taxonomic group. According to Lindenmayer et al. (2012), reasons include "lack of funding, the relatively short working lifespan of the researchers who champion the study and a failure of scientists to communicate effectively the array of values of long-term studies, including their key practical value in informing management and decision making".

When compared to other insects, populations of Neotropical orchid bees (Hymenoptera: Apidae: Euglossina) have been considered as exceptionally stable based on the single long-term study of these important forest pollinators conducted so far (Roubik and Ackerman 1987). Nevertheless, this study was conducted on large and protected areas in central Panama, and it is not known how populations of orchid bees fluctuate in smaller areas or forest remnants under strong anthropogenic pressures. Almost all ecological research on orchid bees aiming to study their phenology and inventory their local faunas are carried out during a single year, with monthly, fortnightly, or weekly samplings (e.g., Ackerman 1983; Rebêlo and Garófalo 1991, 1997; Oliveira and Campos 1996; Nemésio and Silveira 2007, 2010) or even during only one or few consecutive days (e.g., Abrahamczyk et al. 2011; Nemésio and Vasconcelos 2013). More important, once sampled, these areas are usually not sampled again so we do not know whether the seasonal pattern observed represents an annual trend of orchid-bee communities at those sites. Only recently, some areas have been re-sampled, with some strikingly different results-but obtained under different sampling protocols (see Nemésio 2013b; Nemésio and Paula 2013).

The Atlantic Forest of eastern Brazil is one of the most threatened tropical biomes and considered to be one of the 25 earth's biodiversity hotspots (Myers 1988; Mittermeier et al. 1999; Myers et al. 2000). Less than $10 \%$ of the original forest remains, highly fragmented in small forest remnants and frequently surrounded by the largest Brazilian metropolitan areas (Ribeiro et al. 2009). Although these small forest patches, even in urban areas, can sustain viable populations of at least some species of these insects (Bezerra and Martins 2001; Nemésio and Silveira 2007, 2010), many species are considered to be forest dependent (e.g., Morato et al. 1992; Nemésio and Silveira 2006; Nemésio 2010a). Understanding the dynamics of orchid bee populations in such areas is thus essential if the conservation of these bees and the many plant species pollinated by them (reviewed by Dressler 1982) are to be considered. Besides, a thorough comprehension of the population dynamics of orchid-bee species is essential for assessing alternative sampling methodologies, as the few-day inventories advocated by Roubik (2004), Nemésio (2010b, 2011, 2013a, b, c, d) and Abrahamczyk et al. (2011).

The main goals of this study after year-round samplings at the same site in a span of 7 years were to assess stability of (i) orchid bee populations in a small forest patch under strong anthropogenic pressures over the years and (ii) orchid bee community structure, i.e., the relative abundance of each species within a given community.

\section{METHODS}

\subsection{Study area}

Data were collected in a single forest remnant in the city of Belo Horizonte, southeastern Brazil, in which metropolitan area more than three million inhabitants live. Belo Horizonte is at the border of two major Brazilian biomes, the Atlantic Forest and the Cerrado (Brazilian savanna). The dominant forest physiognomy in the region is the semideciduous forest, called "low mountain rain forest" by Rizzini (1979). In these forests, the canopy reaches 15 to $25 \mathrm{~m}$ with tree trunks 40 to $60 \mathrm{~cm}$ in diameter. The forest has a well-developed understory with many juvenile trees but relatively few epiphytes and lianas. Trees grow taller and wider, and spacing between them is reduced in the humid ravines. On the other hand, the forest gets sparser and shorter as the altitude increases, being substituted at the top of the tallest hills by patches of Cerrado or (above $1000 \mathrm{~m}$ ) by rocky fields. The regional climate is the AW of Köppen (tropical with rainy summers and a dry winter with mean annual temperature of $18^{\circ} \mathrm{C}$ ).

The sampling site was located at "Parque das Mangabeiras," located in the southern edge of the city $\left(19^{\circ} 56^{\prime} 55^{\prime \prime} \mathrm{S}, 43^{\circ} 54^{\prime} 12^{\prime \prime} \mathrm{W}\right.$; altitude $\approx 1000 \mathrm{~m}$ a.s.l.). It is surrounded by urbanized land on its northern and western borders and is limited, in its southern border, by a mountain range ("Serra do Curral"). The site has a 
total area of 237 ha, of which 90 ha are covered by forest (mostly secondary forest) and surrounded by 82 ha of Cerrado, 44 ha of fields (mostly anthropogenic), and 21 ha of constructed area. Orchid bees were sampled inside the forest area, in site located about $70 \mathrm{~m}$ from the nearest edge.

\subsection{Sampling}

Male orchid bees were collected at a single fixed spot, between 10:00 and 16:00 hours, when orchid bees are most active at the region, once every month, from April to March of the next year. Monthly samplings were carried out every other year from April 1997 to March 2004, resulting in 48 monthly samplings in 4 years, totaling $288 \mathrm{~h}$ of active sampling with insect nets. This practice was adopted in order to minimize the impact of destructive collecting, thus a full-year interval was always respected between 2-year-round samplings. Five aromatic compounds (1,8-cineole, benzyl acetate, eugenol, methyl trans -cinnamate, and vanillin) were used to attract the bees, since in preliminary tests in this region, these baits were the most attractive to them. The baits were made of cotton swabs soaked with one of the above listed substances. They were placed hanging from branches at about $1.5 \mathrm{~m}$ above the ground and distant ca. $2 \mathrm{~m}$ apart from each other. All bees attracted to these lures were captured with entomological nets, killed with ethyl acetate and pinned. The substance to which each bee was attracted and the day and time of the day it was collected were recorded. All specimens collected are deposited at the entomological collections of the Taxonomic Collections of the "Universidade Federal de Minas Gerais" and of the "Laboratório de Taxonomia de Abelhas" of the "Universidade Federal de Uberlândia". Bees were identified at species level by the first author. Taxonomy follows Nemésio and Rasmussen (2011).

In order to make it easy to refer to each specific yearly sampling, samplings carried out in 1997/1998, 1999/2000, 2001/2002, and 2003/2004 (always from April to March) will be referred to as 1997, 1999, 2001 and 2003, respectively.

\subsection{Climatic data}

Total monthly precipitation and mean monthly temperature were obtained at the meteorological station belonging to "Companhia de Pesquisa de Recursos
Minerais" and situated at "Parque das Mangabeiras", close to the sampling site. Both variables were correlated to monthly bee abundances (Pearson correlation test) over the years.

\subsection{Data analyses}

To determine the level of stability in the population abundances of orchid-bees across different years, we calculated a "stability index" (hereafter SI) commonly employed in studies of insect ecology (e.g., Wolda 1983; Roubik and Ackerman 1987). This index is calculated as the natural logarithm of the variance in annual population abundances (transformed as $\ln \mathrm{x}+1$ ). SI was estimated for each species recorded in our study site. In addition, we calculated a "combined" (i.e., communitywide) SI, which included data for all bee species, except those with a mean natural logarithm of annual abundance $<0.6$, since these, because of their rarity, often have a small variance in abundance (Roubik and Ackerman 1987).

Diversity was estimated through ShannonWiener diversity index $\left(\mathrm{H}^{\prime}\right)$, as $\mathrm{H}^{\prime}=-\Sigma p_{i} \ln$ $\left(p_{i}\right)$, where $p_{i}$ is the proportion of total number of species made up of the $i$ th species. Evenness $(E)$ was estimated through the formula $E=H^{\prime} / \ln (S)$, where $S$ is the species richness. The similarity in faunistic composition among all 4 years was estimated by the percent similarity index of Renkonen, recommended by Wolda (1981) for small samples and strongly recommended by Balmer (2002) since it deals with relative abundances of species.

\section{RESULTS}

\subsection{Community structure}

A total of 2188 orchid-bee males belonging to 14 species were collected in the 4 years of sampling (mean of 547 bees per year) (Table I). Nine species were collected in all 4 years, two species were collected in 3 years, two species were collected in 2 years, and one species, Eufriesea auriceps (Friese), was collected in only 1 year. A total of 12 species was collected in each year, except in 1999 when 11 species were recorded. In all years, the community was dominated by the same five or six species (Figure 1). All other remaining species found in this community were 
Table I. Number of specimens of each orchid-bee species collected at "Parque das Mangabeiras," Belo Horizonte region, southeastern Brazil, in four alternate years, from 1997 to 2004, and diversity, richness and evenness for each year, as well as stability indices (SI) for the six species with a mean natural logarithm of annual abundance $>0.6$ and for the composite community.

\begin{tabular}{llllll}
\hline Species & $1997 / 1998$ & $1999 / 2000$ & $2001 / 2002$ & $2003 / 2004$ & SI \\
\hline Eufriesea auriceps (Friese) & 0 & 0 & 1 & 0 & - \\
Euglossa aratingae Nemésio & 1 & 0 & 0 & 5 & - \\
Eg. carolina Nemésio & 2 & 0 & 1 & 1 & - \\
Eg. fimbriata Moure & 168 & 95 & 72 & 121 & -1.6198 \\
Eg. imperialis Cockerell & 8 & 4 & 2 & 4 & -1.1378 \\
Eg. leucotricha Rebêlo and Moure & 1 & 4 & 0 & 0 & - \\
Eg. melanotricha Moure & 88 & 48 & 30 & 73 & -1.3892 \\
Eg. pleosticta Dressler & 3 & 1 & 2 & 1 & - \\
Eg. securigera Dressler & 32 & 20 & 7 & 12 & -1.1526 \\
Eg. stellfeldi Moure & 157 & 62 & 96 & 82 & -1.5521 \\
Eg. truncata Rebêlo and Moure & 101 & 43 & 53 & 54 & -1.6036 \\
Eulaema nigrita Lepeletier & 236 & 151 & 181 & 152 & -2.0867 \\
El. marcii Nemésio & 0 & 1 & 2 & 2 & - \\
Exaerete smaragdina (Guérin-Méneville) & 3 & 2 & 1 & 2 & - \\
Total & 800 & 431 & 448 & 509 & -1.809 \\
Diversity (H') & 1.76 & 1.74 & 1.60 & 1.75 & - \\
Richness & 12 & 11 & 12 & 12 & - \\
Evenness & 0.71 & 0.72 & 0.64 & 0.71 & - \\
\hline
\end{tabular}
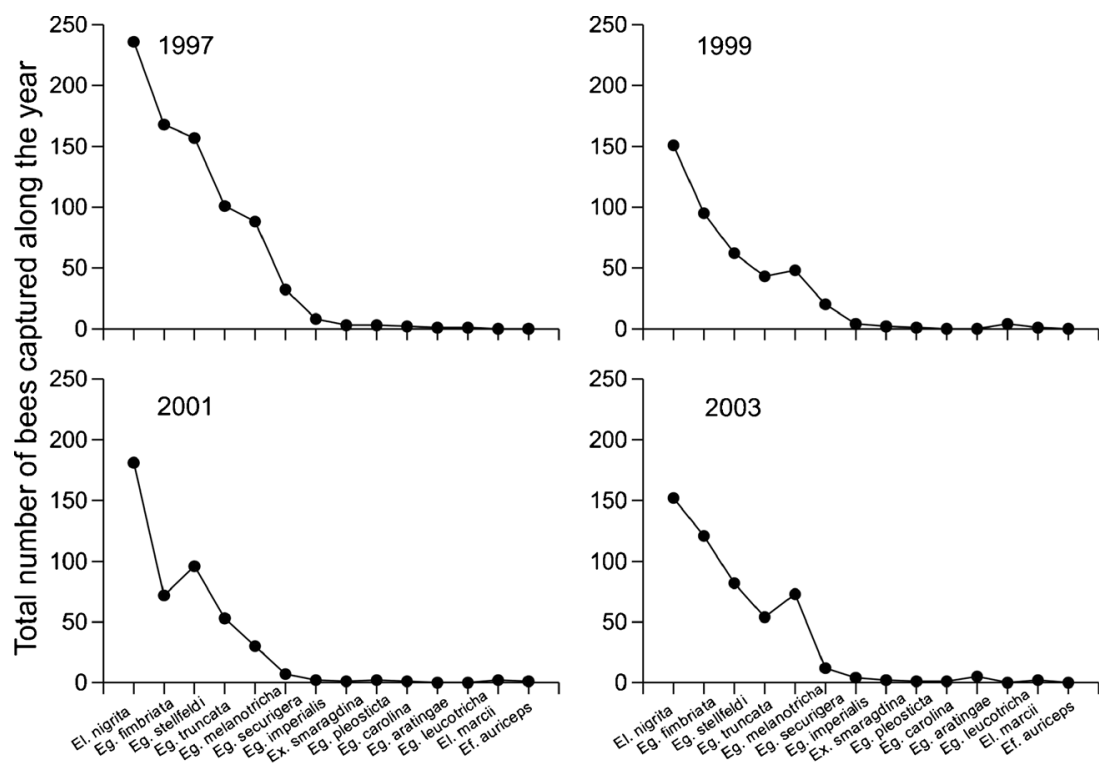

Bee species

Figure 1. Abundance of each orchid-bee species collected at "Parque das Mangabeiras," Belo Horizonte region, southeastern Brazil, in four alternate years, from 1997 to 2004, showing species from the most to the least abundant. 
rare and usually were represented by fewer than three individuals in each year. Eulaema nigrita Lepeletier was the most abundant species in all years (Figure 1); the number of El. nigrita recorded in each year represented from 29.5 to $40.2 \%$ of all bees captured. Euglossa fimbriata Moure was the second most common species in all years, except in 2001, when it was the third most common species in the community. Euglossa stellfeldi Moure was the second most common species in 2001 and the third most common one in the remaining years. Euglossa truncata Rebêlo and Moure and Euglossa melanotricha Moure ranked, respectively, as the fourth and fifth most common species in most years, whereas Euglossa securigera Dressler as the sixth most common species in all years (Figure 1).

\subsection{Seasonal patterns of abundance}

The total number of bees captured in each sampling day varied widely, from only four bees in June 1997 to 219 bees in December 1997. In general, the more bees we captured in a given sampling day the greater the number of species recorded. The correlation between daily bee abundance (log transformed) and species richness was somewhat stronger

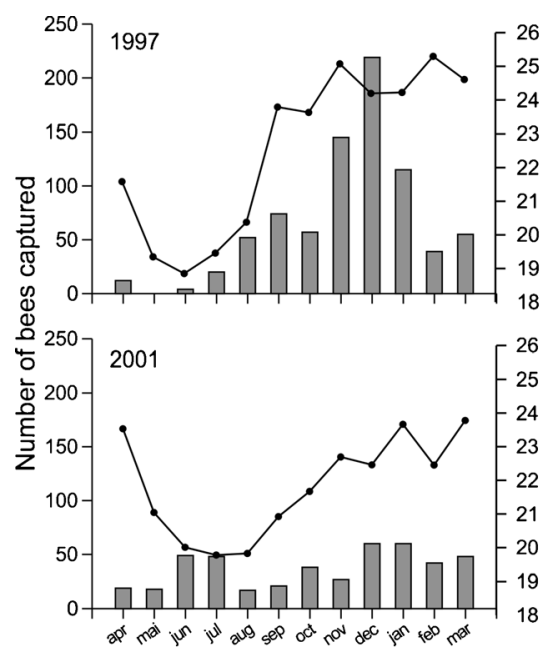

in $1997(r=0.886, P<0.001)$ and $1999(r=$ $0.788, P=0.002)$ than in $2001(r=0.590, P=$ $0.044)$ and $2003(r=0.551, P=0.064)$.

The number of bee captures tended to be higher between September and January than in the remaining months of the year (Figures 2 and 3). However, the observed seasonal fluctuation in the number of bees captured per day was much more marked in 1997 than in the remaining years (Figures 2 and 3). Similar results were obtained for analyses involving each of the six most common species; seasonal fluctuations in the abundance of each of those species tended to be more marked in 1997 than in the remaining years, although for Eg. melanotricha, these fluctuations were also marked in 2003 (Figure 3).

Species diversity $\left(H^{\prime}=1.60\right.$ to 1.76$)$, evenness ( $E=0.64$ to 0.72 ), and richness (11 to 12 species) remained remarkably stable among years. Renkonen similarity index among samplings also showed high values. The first sampling (1997) grouped with the last sampling (2003) with $92.3 \%$ similarity and, then, both periods grouped with the second sampling (1999) with $92.2 \%$ similarity. Finally, these three sampling periods grouped with the third sampling (2001) with $85 \%$ similarity.

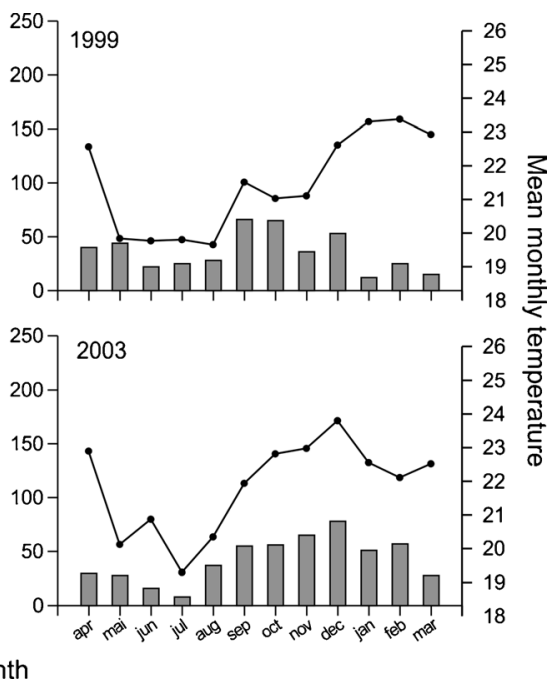

Figure 2. Seasonal fluctuation in the overall abundance of the orchid-bee community (columns) compared to the mean monthly temperature (dotted lines) at "Parque das Mangabeiras," Belo Horizonte region, southeastern Brazil, in four alternate years. 

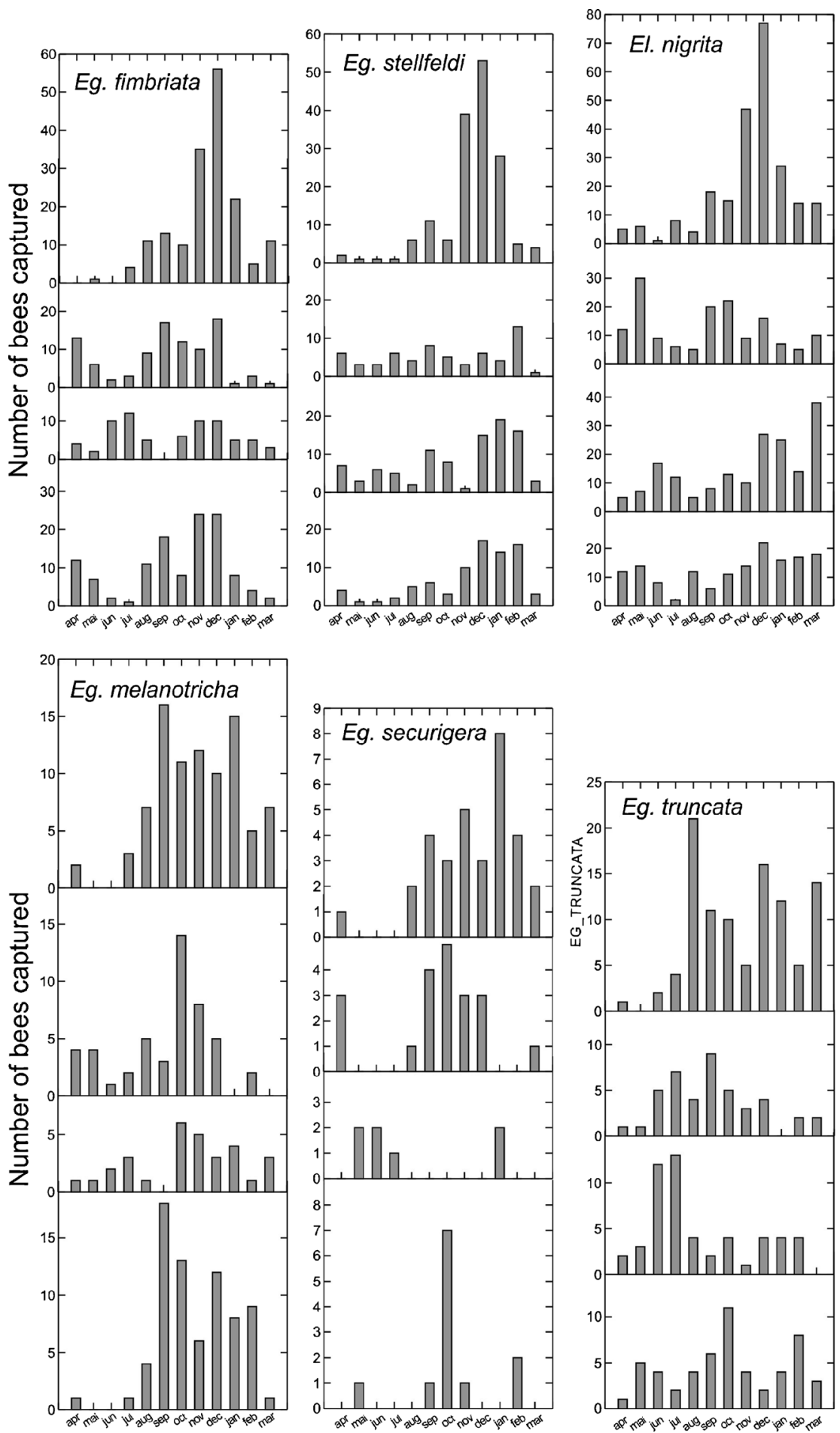

Figure 3. Seasonal fluctuation of populations of the six most abundant orchid-bee species at "Parque das Mangabeiras," Belo Horizonte region, southeastern Brazil, in four alternate years, from 1997 to 2004 . The upper graph for each species corresponds to the first sampling year (1997/1998) and the bottom graph the last year (2003/2004). 


\subsection{Climatic data}

Both climatic variables, total monthly precipitation and mean monthly temperature, were positively correlated with total monthly bee abundance in the first and fourth sampling years (Table II).

\subsection{Stability indices}

We found a "combined" SI of -1.81 for the orchid-bee community recorded in our study site. Stability indices calculated for each individual species ranged from -1.13 (for Euglossa imperialis Cockerell, the least stable species) to -2.09 (for El. nigrita, the most stable species) (see Table I). Overall, the observed interspecific variation in SI was not explained by variations in species mean annual abundances $(r=-0.454, n=$ $14, P=0.103)$ (Figure 4). However, when only the six most abundant species were considered, then a significant relationship between stability and abundance was detected $(r=-0.901, n=6, P=$ 0.014 ); the more abundant species tended to present less variation in their population abundances than the less abundant ones (Figure 4).

\section{DISCUSSION}

The faunistic composition of the orchid-bee community at the sampled site is typical of semideciduous forests of southeastern Brazil, regarding both the number and the identity of

Table II. Correlation of two climatic variables, total monthly precipitation and mean monthly temperature, with bee monthly abundance (log transformed) at "Parque das Mangabeiras," Belo Horizonte region, southeastern Brazil, in four alternate years, from 1997 to 2004 .

\begin{tabular}{llllll}
\hline Year & \multicolumn{2}{l}{ Precipitation } & & \multicolumn{2}{l}{ Temperature } \\
\cline { 2 - 3 } \cline { 5 - 6 } & $r$ & $P$ & & $r$ & $P$ \\
\hline 1997 & 0.540 & 0.070 & & 0.798 & 0.002 \\
1999 & -0.337 & 0.284 & & -0.240 & 0.452 \\
2001 & 0.447 & 0.145 & & 0.244 & 0.444 \\
2003 & 0.531 & 0.076 & & 0.772 & 0.003 \\
\hline
\end{tabular}

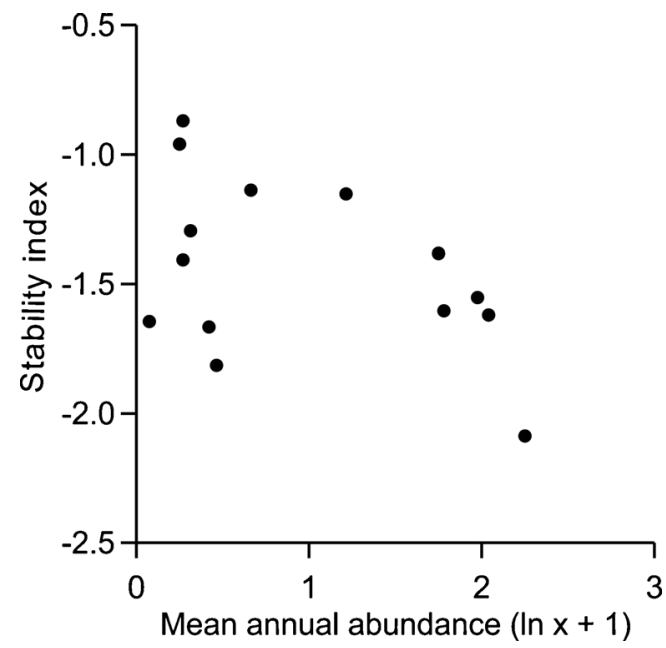

Figure 4. Correlation between the stability index and mean annual abundance of each orchid-bee species collected at "Parque das Mangabeiras," Belo Horizonte region, southeastern Brazil, in four alternate years, from 1997 to 2004.

species (e.g., Rebêlo and Garófalo 1991, 1997; Nemésio and Silveira 2007, 2010). None of the species recorded here represented a new record for the area or was unexpected to occur in the region. Only two additional orchid-bee species are known from the region of Belo Horizonte and were not recorded in the present study: Eufriesea nigrohirta (Friese), a species also known to occur at "Parque das Mangabeiras" (Nemésio and Silveira 2007) but only recorded at the rockyfield physiognomy and Eulaema seabrai Moure, a species known from a nearby area but which males are usually not attracted to the commonly used synthetic fragrances (Nemésio and Silveira 2004).

Abundance tended to be fairly stable considering the assemblage of orchid bees as a whole, even though during the first sampling year the number of bees captured was almost twice as high as during subsequent years. This pattern was also reported by Roubik and Ackerman (1987: 323), who observed a decrease in abundance for the first 2 years at two of three studied sites, after which it increased and stabilized. A second observed pattern was the higher abundance of bees from September to January, when compared to the other months. It should be stressed that the region of 
Belo Horizonte presents well-defined dry and cold (from April to August) and wet and hot (from September to March) seasons (see Figure 2). It has long been shown that most orchid-bee species are usually associated with humid environments (e.g., Dressler 1982; Roubik and Hanson 2004) and in areas with sharply defined precipitation regimes, as happens to be the case at our sampled area, they are more abundant during the hot rainy season (e.g., Rebêlo and Garófalo 1991, 1997; Bezerra and Martins 2001; Tonhasca et al. 2002; see also Figure 2).

It is remarkable that the community structure remained almost unchanged through the years, with the same dominant and the same rare species ranked roughly at the same positions (Table I, Figure 1). It has been shown that orchid-bee communities along the entire Neotropical region are usually dominated by a few species, whereas a larger number of species occurs as rare species in any given community (Nemésio 2007). The dominant species at "Parque das Mangabeiras" are usually species highly tolerant to open or disturbed areas (e.g., El. nigrita and Eg. fimbriata), to higher altitudes (e.g., Eg. melanotricha and Eg. stellfeldi), or to areas with a highly seasonal precipitation regime (e.g., Eg. truncata). On the other hand, rare species in the present study, such as Eg. imperialis, are usually the most abundant species in highly humid areas (e.g., Roubik and Ackerman 1987; Nemésio 2013a, b, c, d). This latter is probably a species on the edge of its range where it is expected to not be as common as elsewhere.

The stability index for the entire orchid-bee fauna observed in the present study $(-1.81)$ was higher than that observed by Roubik and Ackerman (1987) for three different orchid-bee communities in Panama $(-1.705,-1.502$, and -1.342 , respectively). Our index corresponded to a total of six species that were not rare at the sampled site. The highest SI for a particular species observed in the present study ( -2.09 for $E l$. nigrita), however, was lower than that observed for many orchid-bee species in Panama, where the highest observed SI was -4.12 (Roubik and Ackerman 1987). Negative values are reported to be the most stable and SI values for insect assemblages studied for long periods of time prior to the study of Roubik and Ackerman (1987) have ranged between -1.614 and 1.158 (Wolda 1983). As observed in Roubik and Ackerman's (1987) study, abundance in the present study was also correlated with population stability. Our data revealed one of the most stable assemblages of insects ever recorded, comparable to the most stable known insect populations (see Owen 1978; Wolda 1983; Wolda and Roubik 1986; Roubik and Ackerman 1987). Even the least stable orchid-bee populations are still relatively stable (negative values).

Roubik and Ackerman (1987:331) suggested that the high stability of orchid-bee populations is due to a combination of traits unique for these bees, such as (i) the fact that successive generations of bees use the same nest reducing the problems of finding a suitable nesting site and nest materials; (ii) most nectar sources of orchid bees, which are long-tongued insects, are inaccessible to flower visitors unable to reach nectar through long corollas; (iii) their nectar sugar concentration preferences are also different from other tropical bees; and (iv) that orchid bees hover and fly with great efficiency and through long distances, making them thus better able to exploit scattered resources, a fact long known (Janzen 1971). If this is true, conservation of these forest patches is essential when one takes into account orchid-bee conservation, since three of the four aspects listed by Roubik and Ackerman (1987) are directly or indirectly related to environmental characteristics only present in forested environments, such as presence of adequate nesting sites and presence of particular plant species which provide nourishment for the bees. In a forest patch immersed in an urban matrix, these features are theoretically of greater importance, since there are no alternative habitats for these bees.

That our results showed that orchid-bee populations and the orchid-bee community structure may be relatively stable over the years is not particularly surprising, since a previous study had already shown similar results (Roubik and Ackerman 1987). Our data are noticeable; however, when one considers that our study was carried out at a small forest patch inserted in a metropolitan area with more than 3,000,000 people and all possible direct consequences of human 
impact in a developing country, i.e., in an area where anthropogenic pressures could be expected to destabilize local communities. Nemésio and Silveira (2007, 2010), studying the orchid-bee faunas of several forest fragments in the same region, including "Parque das Mangabeiras," during only 1 year suggested that forest fragments in large urban areas might effectively support viable populations of orchid bees and that conservation of these areas should then be encouraged. At the time, those authors also considered that the mere presence of a species does not mean that its preservation is granted, since some orchid-bee species in such forest patches might be represented by the last generations of declining populations, remnants of larger ones that previously occupied larger areas, now doomed to extinction due to rapid deforestation (Nemésio and Silveira 2007). Monitoring of such populations at the largest and best preserved of the forest remnants in the region during a seven-year span, with four year-round samplings in between, support the original interpretation that forest remnants even in urban areas are able to maintain viable populations of these important pollinators over time.

\section{ACKNOWLEDGMENTS}

We are grateful to "Prefeitura Municipal de Belo Horizonte", through the administration of "Parque das Mangabeiras," for allowing us to conduct this study. Ernesto de Oliveira A. Lemes and "Companhia de Pesquisa de Recursos Minerais" made the climatic data available to us. We also thank James D. Ackerman and two anonymous referees for reading and commenting on an earlier version of this manuscript.

Ecologie à long terme des abeilles à orchidées dans une forêt urbaine relictuelle

Forêt atlantique / structure d'une communauté / conservation / Euglossini / dynamique des populations / index de stabilité

Langzeitökologie von Prachtbienen in einem innerstädtischen Waldstück

Atlantischer Regenwald / Struktur der Gemeinschaften / Prachtbiene / Euglossini / Populationsdynamik / Stabilitätsindex

\section{REFERENCES}

Abrahamczyk, S., Gottleuber, P., Matauschek, C., Kessler, M. (2011) Diversity and community composition of euglossine bee assemblages (Hymenoptera: Apidae) in western Amazonia. Biodivers. Conserv. 20, 29813001

Ackerman, J.D. (1983) Diversity and seasonality of male euglossine bees (Hymenoptera: Apidae) in Central Panama. Ecology 64, 274-283

Balmer, O. (2002) Species lists in ecology and conservation: abundances matter. Cons. Biol. 16, 1160-1161

Bezerra, C.P., Martins, C.F. (2001) Diversidade de Euglossinae (Hymenoptera: Apidae) em dois fragmentos de Mata Atlântica localizados na região urbana de João Pessoa, Paraíba. Brasil. Rev. Bras. Zool. 18, 823-835

Dressler, R.L. (1982) Biology of the orchid bees (euglossini). Annu. Rev. Ecol. Syst. 13, 373-394

Holmes, R.T., Sherry, T.W. (2001) Thirty-year bird population trends in an unfragmented temperate deciduous forest: importance of habitat change. Auk 118, 589609

Janzen, D.H. (1971) Euglossini bees as long-distance pollinators of tropical plants. Science 171, 203-205

Krebs, C.J., Boutin, S., Boonstra, R. (2001) Ecosystem Dynamics of the Boreal Forest: The Kluane Project. Oxford University Press, NewYork

Lindenmayer, D.B., Likens, G.E. (2010) Effective Ecological Monitoring. CSIRO Publishing and Earthscan, Melbourne and London

Lindenmayer, D.B., Likens, G.E., Andersen, A., Bowman, D., Bull, C.M., Burns, E., Dickman, C.R., Hoffmann, A.A., Keith, D.A., Liddell, M.J., et al. (2012) Value of long-term ecological studies. Austral Ecol. 37, 745757

Mittermeier, R.A., Myers, N., Gil, P.R., Mittermeier, C.G. (1999) Hotspots: Earth's biologically richest and most endangered terrestrial ecoregions. CEMEX, Mexico

Morato, E.F., Campos, L.A.O., Moure, J.S. (1992) Abelhas Euglossini (Hymenoptera, Apidae) coletadas na Amazônia Central. Rev. Bras. Entomol. 36, 767-771

Myers, N. (1988) Threatened biotas: "hotspots" in tropical forests. Environmentalist 8, 187-208

Myers, N., Mittermeier, R.A., Mittermeier, C.G., Fonseca, G.A.B..., Kent, J. (2000) Biodiversity hotspots for conservation priorities. Nature 403, 853-858

Nemésio, A. (2007) The community structure of male orchid bees along the Neotropical region. Rev. Bras. Zooc. 9, 151-158

Nemésio, A. (2010a) Eulaema (Apeulaema) felipei sp. n. (Hymenoptera: Apidae: Euglossina): a new forestdependent orchid bee found at the brink of extinction in northeastern Brazil. Zootaxa 2424, 51-62

Nemésio, A. (2010b) The orchid-bee fauna (Hymenoptera: Apidae) of a forest remnant in northeastern Brazil, with new geographic records and an identification key to the 
known species of the Atlantic Forest of northeastern Brazil. Zootaxa 2656, 55-66

Nemésio, A. (2011) Euglossa marianae sp. n. (Hymenoptera: Apidae): a new orchid bee from the Brazilian Atlantic Forest and the possible first documented local extinction of a forest dependent orchid bee. Zootaxa 2892, 59-68

Nemésio, A. (2013a) The orchid-bee fauna (Hymenoptera: Apidae) of 'Reserva Biológica de Una', a hotspot in the Atlantic Forest of southern Bahia, eastern Brazil. Braz. J. Biol. 73, 347-352

Nemésio, A. (2013b) Are orchid bees at risk? First comparative survey suggests declining populations of forest-dependent species. Braz. J. Biol. 73, 367-374

Nemésio, A. (2013c) The orchid-bee faunas (Hymenoptera: Apidae) of two Atlantic Forest remnants in southern Bahia, eastern Brazil. Braz. J. Biol. 73, 375-381

Nemésio, A. (2013d) The orchid-bee faunas (Hymenoptera: Apidae) of 'Parque Nacional do Monte Pascoal', 'Parque Nacional do Descobrimento' and three other Atlantic Forest remnants in southern Bahia, eastern Brazil. Braz. J. Biol. 73, 437-446

Nemésio, A., Paula, I.R.C. (2013) The orchid-bee fauna (Hymenoptera: Apidae) of 'RPPN Feliciano Miguel Abdala' revisited: relevant changes in community composition. Braz. J. Biol. 73, 515-520

Nemésio, A., Rasmussen, C. (2011) Nomenclatural issues in the orchid bees (Hymenoptera: Apidae: Euglossina) and an updated catalogue. Zootaxa 3006, 1-42

Nemésio, A., Silveira, F.A. (2004) Biogeographic notes on rare species of Euglossina (Hymenoptera: Apidae: Apini) occurring in the Brazilian Atlantic Rain Forest. Neotropical Entomol. 33, 117-120

Nemésio, A., Silveira, F.A. (2006) Edge effects on the orchid-bee fauna (Hymenoptera: Apidae) at a large remnant of Atlantic Forest in southeastern Brazil. Neotropical Entomol. 35, 313-323

Nemésio, A., Silveira, F.A. (2007) Orchid bee fauna (Hymenoptera: Apidae: Euglossina) of Atlantic Forest fragments inside an urban area in southeastern Brazil. Neotropical Entomol. 35, 186-191

Nemésio, A., Silveira, F.A. (2010) Forest fragments with larger core areas better sustain diverse orchid bee faunas (Hymenoptera: Apidae: Euglossina). Neotropical Entomol. 39, 555-561

Nemésio, A., Vasconcelos, H.L. (2013) Beta diversity of orchid bees in a tropical biodiversity hotspot. Biodivers. Conserv. 22, 1647-1661

Oliveira, M.L., Campos, L.A.O. (1996) Preferências por estratos florestais e por substâncias odoríferas em abelhas Euglossinae (Hymenoptera, Apidae). Rev. Bras. Zool. 13, 1075-1085

Owen, D.F. (1978) Abundance and diversity of bumblebees and cuckoo bees in a suburban garden. Entomol. Rec. 90, 242-244

Rebêlo, J.M.M., Garófalo, C.A. (1991) Diversidade e sazonalidade de machos de Euglossini (Hymenoptera, Apidae) e preferência por iscas odores em um fragmento de floresta no sudeste do Brasil. Rev. Bras. Biol. 51, 787-799

Rebêlo, J.M.M., Garófalo, C.A. (1997) Comunidades de machos de Euglossinae (Hymenoptera, Apidae) em matas semidecíduas do nordeste do estado de São Paulo. An. Soc. Entomol. Bras. 26, 243-256

Ribeiro, M.C., Metzger, J.P., Martensen, A.C., Ponzoni, F.J., Hirota, M.M. (2009) The Brazilian Atlantic forest: how much is left, and how is the remaining forest distributed? Implications for conservation. Biol. Conserv. 142, 1141-1153

Rizzini, C.T. (1979) Tratado de fitogeografia do Brasil. v. 2. Aspectos sociológicos e florísticos. HUCITEC \& USP, São Paulo

Roubik, D.W. (2004) Long-term studies of solitary bees: what the orchid bees are telling us. In: Solitary bees: Conservation, rearing, management for pollination, B. M. Freitas \& J. O. Pereira (eds), Imprensa Universitária, Fortaleza, pp. 97-103

Roubik, D.W., Ackerman, J.D. (1987) Long-term ecology of euglossine orchid-bees (Apidae, Euglossini) in Panama. Oecologia 73, 321-333

Roubik, D.W., Hanson, P. (2004) Orchid bees of Tropical America: biology and field guide. INBIO, San Jose

Strayer, D.L., Glitzenstein, J.S., Jones, C., Kolasa, J., Likens, G.E., McDonnell, M.J., Parker, G.G., Pickelt, S.T.A. (1986) Long-Term Ecological Studies: An Illustrated Account of Their Design, Operation, and Importance to Ecology. Occasional Publication no. 2. Institute of Ecosystem Studies. Institute of Ecosystem Studies, Millbrook

Tonhasca Jr., A., Blackmer, J.L., Albuquerque, G.S. (2002) Abundance and diversity of euglossine bees in the fragmented landscape of the Brazilian Atlantic Forest. Biotropica 34, 416-422

Wolda, H. (1981) Similarity indices, sample sizes and diversity. Oecologia 50, 296-302

Wolda, H. (1983) Long-term stability of tropical insect populations. Res. Popul. Ecol. Suppl. 3, 112-126

Wolda, H., Roubik, D.W. (1986) Nocturnal bee abundance and seasonal bee activity in a Panamanian forest. Ecology $67,426-433$ 